doi: $10.26529 /$ cepsj. 513

\title{
The Missing Link: Teacher Learning for Diversity in an Area-based Initiative in Portugal
}

Nikolett Szelei ${ }^{* 1}$ ANd Ines Alves ${ }^{2}$

$\approx$ As an attempt to promote educational success in socio-economically disadvantaged contexts, area-based initiatives are often launched in Europe, such as the programme Territórios Educativos de Intervenção Prioritária in Portugal. Given the importance of teaching quality to enhance student learning and considerable student diversity in the schools included in this initiative, this article explores opportunities for teacher learning for diversity within the programme. Documentary analysis was conducted on 188 school documents from 95 school clusters in the programme. The following research questions were asked: Does the programme promote teacher learning? In what ways is teacher learning promoted? Does teacher learning address diversity? The findings suggest that some interventions provide the possibility of teacher learning, such as the processes of learning together, pedagogical supervision, reflection, and attending professional development courses. However, diversity seemed to be largely missing from these initiatives. Furthermore, two cornerstones of teacher learning for diversity were absent: teachers' critical reflection on students' inclusion/exclusion; and learning from/with students, families, and communities. Additionally, most professional development opportunities were organised around and measured by students' academic results, thus positioning teacher learning as instrumental in raising school success, rather than a core of transforming education for diversity. These results call for policies within the Territórios Educativos de Intervenção Prioritária programme to include teacher learning that engages with and fosters critical thinking around diversity and to involve communities' and students' voices in order to truly tackle social exclusion. The findings can contribute to the debate on the approach to diversity in area-based initiatives in Europe.

Keywords: area-based initiatives, diversity, professional development, teacher learning

$1 \quad{ }^{*}$ Corresponding Author. Instituto de Educação da Universidade de Lisboa, Potrugal; nszelei@ie.ulisboa.pt.

2 University of Glasgow, Scotland. 


\section{Manjkajoči člen: učenje učiteljev za raznolikost $\mathrm{v}$ področno zasnovani iniciativi na Portugalskem}

Nikolett Szelei in Ines Alves

$\propto$ Področno zasnovane iniciative, kot je na primer Territórios Educativos de Intervenção Prioritária na Portugalskem, so v Evropi pogosto izvedene z namenom spodbujanja edukacijskih uspehov v socialno-ekonomsko deprivilegiranih kontekstih. Glede na pomen kakovosti poučevanja za izboljševanje učenja učencev ter glede na znatno raznolikost učencev in učenk v šolah, ki so bile vključene v omenjeno iniciativo, ta prispevek raziskuje priložnosti za učenje učiteljev za raznolikost znotraj omenjenega programa. Izvedena je bila analiza 188 šolskih dokumentov iz 95 šolskih skupin v programu. Postavljena so bila naslednja raziskovalna vprašanja: Ali program spodbuja učenje učiteljev? Na katere načine spodbuja učenje učiteljev? Ali učenje učiteljev naslavlja raznolikost? Ugotovitve kažejo, da nekatere intervencije nudijo možnosti za učenje učiteljev, kot so na primer: procesi skupnega učenja, pedagoška supervizija, refleksija in obiskovanje kurzov za profesionalni razvoj. Kljub temu pa se zdi, da raznolikost $\mathrm{v}$ tovrstnih iniciativah pogosto umanjka. Dva temelja učenja učiteljev za raznolikost sta bila namreč odsotna: kritična refleksija učiteljev o vključenosti/izključenosti učencev; učenje od učencev/z učenci, od družin/z družinami in od skupnosti/s skupnostmi. Ob tem je bila večina priložnosti za profesionalni razvoj organizirana in merjena s šolskim uspehom učencev, kar pomeni, da je učenje učiteljev le instrument za izboljšanje šolskega uspeha učencev, ne pa kot jedro spremembe izobraževanja za raznolikost. Ti izsledki kličejo k politikam znotraj programa Territórios Educativos de Intervenção Prioritária, ki bodo morale, če se želijo resnično spoprijeti s socialno izključenostjo, vključevati učenje učiteljev, ki upošteva in goji kritično razmišljanje o raznolikosti, ter glasove skupnosti in učencev. Ugotovitve lahko prispevajo k razpravi o pristopu k raznolikosti v okvirih področno zasnovanih iniciativ v Evropi.

Ključne besede: področno zasnovane iniciative, raznolikost, profesionalni razvoj, učenje učiteljev 


\section{Introduction}

Education is a fundamental right for all; however, schools are generally not geared to respond to the growing student diversity in a way that guarantees equity. Student diversity has become one of the most significant challenges for schools in the $21^{\text {st }}$ century (Ainscow, 2016). This challenge seems to be more present in socio-economically disadvantaged areas where area-based initiatives (ABIs) (Kerr \& Dyson, 2017) are often launched (Dyson, Raffo, \& Rochex, 2014). Student diversity is sometimes overlooked in ABIs, where 'areas' are treated as administrative units rather than human ecologies (Lupton, 2010). On reviewing the results of ABIs, Dyson et al. (2014) indicate the need to collect data that allows controlling for the impact of gender, ethnicity and social class (Dyson, Raffo, \& Rochex, 2014) and not only focus on the impact on students' school results in general. Teachers are a crucial component in students' success (Darling-Hammond, 2017; Hattie, 2003). However, teachers working in such policy contexts that define success narrowly in terms of school results, often experience tensions between the claimed values of inclusion and diversity and the priorities with which they must comply (Dyson, Gallanaugh, \& Millward, 2003). Little is known about how teacher learning for diversity is promoted in TEIP, an ABI in Portugal.

\section{TEIP, an area-based initiative in Portugal}

Area-Based Initiatives (ABIs) are often initiated in order to tackle underachievement, disadvantage, and social exclusion in Europe. Zones déducation prioritaires in France, Excellence in Cities in England, or the Territórios Educativos de Intervenção Prioritária in Portugal are examples of ABIs. Dyson et al. (2014) suggest that educational priority policies can target individuals (e.g., $\mathrm{SEN})$, groups (e.g., Portuguese as non-mother-tongue language (PNML)), schools (e.g., establishing better leadership), and geographical areas (ABIs, e.g., TEIP). ABIs may combine these three targets.

The TEIP policy was first introduced in Portuguese educational policy in 1996. It was interrupted for a number of years and then was restarted in 2008 as TEIP2 and in 2012 as TEIP 3 (Ferraz et al., 2014). Presently, TEIP 3 includes 137 school clusters and aims at reducing school dropout, truancy, and indiscipline, and promoting educational success. The TEIP programme covers diverse contexts (Abrantes et al., 2013): socially excluded urban areas, diffuse peripheral zones, heterogeneous urban zones with social inequalities and conflicts, and poor rural areas. Abrantes, Mauritti, and Roldão (2011) identified that TEIP 
documents were mostly concerned with preventing school failure, indiscipline, and improving school results and family-school relations. Their research also reviewed the areas of TEIP actions: organisational interventions, pedagogical practices, integrating and monitoring students, as well as extracurricular and community activities. The detected pedagogical strategies predominantly provided more individualised teaching and learning in or outside the classroom, facilitated by a co-teacher or support staff, broadly aiming at improving teaching, reinforcing the subjects Mathematics and Portuguese, experimental Science teaching, and valuing achievement. However, they concluded that measuring TEIP outcomes through the students' school results at national exams might 'reduce the conceptions and practices that guide these actions, limiting the potential of pedagogical and organisational innovation' (p. 28). Although previous studies on TEIP acknowledge the decrease in dropout and indiscipline, the improvement of academic results and educational management, and that some responses have been given to socio-cultural diversity, several authors still question its overall success in transforming education (Abrantes et al., 2011, 2013; Dias, 2013; Rolo, Prata, \& Dias, 2014; Sampaio \& Leite, 2015; Silva, da Silva, \& Araújo, 2017).

Additionally, Canário (2004) shed light on the TEIP schools' deficit approach to the ABIs' communities and students' families. The author problematises the perspective that longs for homogeneity, undervalues students' experiences, and considers pupils and their families as the sources of problems in schooling. Given the importance of teacher learning to student learning, teachers' learning for diversity could be a crucial driving force in TEIP. However, despite the number of studies conducted on TEIP, less is known about how teacher learning for diversity is framed by the TEIP intervention.

\section{Teacher learning}

Teacher effectiveness has rapidly risen to the top of the education policy agenda, as many nations have become convinced that teaching is one of the most important school-related factors in student achievement (OECD). And teacher preparation and development are key building blocks in developing effective teachers. (Darling-Hammond, 2017, p. 291)

Several authors regard teacher learning as conducive to student learning (Guerriero, 2017; Hattie, 2009, 2015; Vermunt, 2014). Teacher learning can be an overarching concept 'that sees teachers as lifelong learners and includes teachers' formal learning in initial teacher education, induction and continuing 
professional development, as well as informal learning such as professional collaborations or networking' (Révai \& Guerriero, 2017, p. 65). Teacher learning is conceptualised as ongoing, social, situated, distributed, and actively constructed (Borko, 2004; Putnam \& Borko, 2000; Webster-Wright, 2009). According to Vermunt and Endedijk (2011), teacher learning is a dynamic interaction between learning and regulating activities, teachers' knowledge, beliefs and learning motivation, and is affected by several contextual and personal characteristics. In this article, we focus on teacher learning in terms of in-service professional development for teachers in TEIP schools.

Changes to the school population and educational reforms require considerable changes in classroom practices. According to Borko (2004), these changes can only happen through supported and guided teacher learning ( $\mathrm{p}$. 3). However, Darling-Hammond (2017) states that professional development remains inadequate and 'in-service seminars and other forms of professional development are fragmented, intellectually superficial' (p. 465). In contrast, teachers also learn in their school context by doing, experimenting, reflecting, and interacting with others (Bakkenes \& Vermunt, 2010; Meirink, Meijer, \& Verloop, 2009). Consequently, teachers should be given opportunities for embedded forms of professional learning and sharing their experiences and expertise in various ways in order to continue developing, learning and being enthusiastic about the teaching profession. These opportunities can include teachers' work with curriculum development through collaborative planning, lesson study, and action research of various kinds (Darling-Hammond, 2017, p. 303). Caena (2011) outlined seven forms of effective professional learning: analysing school culture, peer observations, classroom studies about students' assignments, analysing student data, forming study groups, being involved in development and improvement processes, and studying students' classroom behaviour.

However, often teachers still struggle or resist learning new knowledge and changing practices (Bakkenes \& Vermunt, 2010), especially in the field of diversity (Gay, 2013). In order to enable in-service teacher learning and professional development, a variety of learning experiences and activities explicitly aiming at developing in-service teachers' knowledge, skills, practices, abilities, and values (Cordingley \& Buckler, 2014; Day \& Sachs, 2004; Guskey, 2000; Timperley, 2008;), must be provided. Professional development programmes are most adequate when competency- and reflection-based approaches are integrated in a dynamic model, including the acquisition of specific skills connected to teachers' practice, content responsive to teachers' needs and contexts, teachers' active participation, collaboration, formative evaluation, and sufficient 
timeframes for development (Creemers, Kyriakides, \& Antoniou, 2013). This integrated vision of professional development is important in order not to simply acquire a set of prescribed contents and skills, but to develop moral responsibility to contribute to socially just schooling (Creemers et al., 2013).

Professional development can occur at a variety of sites, such as in school, in networks of schools or in partnerships with other institutions (Day \& Sachs, 2004). Current understandings of professional learning point to the need for professional development to be continuous, related to teachers' actual needs and practice, collaborative, based on research evidence, engaging and empowering for teachers, and aimed at enhancing student learning (European Commission, 2013; Gilbert, 2011; Gimmert, 2014; Menter, 2010). To meet these demands, the school itself is an essential platform for professional development. Situated in the boundary of school contexts, teachers' co-learning and collaboration have been found to be an effective form of teacher learning (Avalos, 2011; Burbank \& Kauchak, 2003; Vescio et al., 2008). According to Vangrieken et al. (2015), teachers' collaboration can occur in teacher teams, learning groups, communities of practice, professional learning communities, and other forms, such as critical friends or networks. Additionally, effective forms of learning together can also be, among others, lesson study (Murata, 2011), mentoring (Kemmis et al., 2014), and peer coaching (Cordingley \& Buckler, 2014). Specifically, in Portugal, 'pedagogical supervision' has been promoted as an effective form of professional development (Carlos et al., 2017).

Regarding teachers in Portugal, Flores (2005) found that teachers undervalued formal learning opportunities provided by teacher education institutions; instead, they preferred school-based activities, such as reflecting on their own practices, analysing students' reactions, and trying out new strategies on a trial-and-error basis. Professional development in Portugal is regulated by the Decree-Law 22/2014, stating that improving the quality of education is one of the key challenges and, with a view to reaching this target, professional development is considered a priority. It furthermore requires professional development to take into account the contextual and individual needs of teachers, and to be based on a needs assessment, followed by a 'Professional Development Plan'. DL22/2014 portrays professional development as a way to support teachers in developing educational and curricular projects, improving their performance, quality, and efficacy and thereby adding to the quality of education and of student results at large. 


\section{Teacher learning for diversity}

Diversity, a traditionally somewhat overlooked area of teacher learning, has been gaining more attention in European policy guidelines (European Agency for Development in Special Needs Education, 2012; European Council, 2009, 2016; European Commission, 2015, 2017; OECD, 2010) over the last decade. In this article, the concept of diversity is understood as multifaceted, socially constructed, and dependent on context. This holistic view on diversity (Cardona Moltó et al., 2010; Essomba, 2010; Timperley \& Alton-Lee, 2008; Waitoller \& Artiles, 2013) covers several aspects such as culture, ethnicity, language, disability, social and economic status, religion, gender, sexual orientation, and so on. These dimensions do not stand in isolation, but their possible intersections as manifested in student populations (Waitoller \& Artiles, 2013) and in the demographics of ABIs are taken into account. Consequently, teacher learning for diversity in this article refers to professional development for inservice teachers addressing a wide scope of student diversity, thus tackling all types of marginalisation and exclusion (Unesco, 2005).

Although diversity has become a regular component in initial teacher education, teachers still report unpreparedness in responding to diversity across Europe (Arnesen et al., 2008; Burns \& Shadoian-Gersing, 2010; European Commission, 2015, 2017) and in Portugal (Flores \& Ferreira, 2016). A few frameworks have been developed for professional learning for diversity. Timperley and Alton-Lee (2008, p. 342) outlined a model that embeds professional development in the socio-cultural and learning environment and regards contents for diversity, teachers' learning activities and learning processes as an interactive system, leading to responding to diversity, and eventually, impacting diversity. Florian (2012) argues that professional development for diversity has to cover three main themes: understanding learning where difference is taken into account, understanding social justice, and becoming active professionals in developing new ways of working together. Waitoller and Artiles' (2013) review on professional development for inclusion described that the main forms of professional development were formal courses (university, on-site or online) and action research projects or collaborations with universities, researchers, and specialists. These projects involved teacher inquiry, as well as several forms of observation, coaching, and collaboration by and with external experts. However, more studies are necessary in order to understand professional development for diversity as it is organised by schools. Some investigations support the idea of lesson studies (Messiou et al., 2016; Simon, Echeita, \& Sandoval, 2018), professional learning communities (Read et al., 2015; Torrico et al., 2016), and 
coaching (Teemant, 2015); with a specific focus on listening to or engaging with students' voice in these approaches (Messiou et al., 2016, Schultz, 2003; Simon et al., 2018). It also has been found fruitful for teachers to work with and learn from communities in diverse contexts (Coffey, 2010; Lees, 2016).

Ainscow (2005), when referring to teachers' 'levers for change', considers 'policy documents, conferences and in-service courses' as low leverage activities, since they do not necessarily create 'interruptions that help to 'make the familiar unfamiliar' in ways that stimulate self-questioning, creativity and action' (p. 116). Ainscow (2005) also states that deeply rooted assumptions about diversity might undermine pedagogical innovations when teachers believe that students are 'disadvantaged and in need of fixing, or, worse, as deficient and, therefore, beyond fixing' (p. 117).

Consequently, drawing on these theoretical perspectives, professional development for diversity includes 1) developing subject content and pedagogical content knowledge in which diversity is included; 2) learning from/with students, families and communities; 3 ) reflecting critically on one's own beliefs and assumptions about diversity, as well as on how teaching practice contributes to socially just schooling. As previous research has shown, it is advisable that these learning processes occur in collaborative environments. There are several possible factors influencing teacher learning due to its situated nature (Avalos, 2011; Borko, 2004; Hoban, 2002; Putnam \& Borko, 2000; Vermunt \& Endedijk, 2011). In this article, teacher learning is approached as represented in school documents in the TEIP policy context.

This study aimed at describing how teacher learning is promoted in the proposed TEIP actions. Furthermore, it was explored how diversity was situated within those teacher learning possibilities. The following research questions were asked:

1. Does TEIP promote teacher learning?

2. In what ways is teacher learning promoted?

3. Does teacher learning within TEIP address student diversity?

\section{Method}

To study teacher learning for diversity, contextualised in TEIP, a microlevel policy analysis was conducted including publicly available documents produced by TEIP schools. Documents were regarded as sources revealing distinct aspects of social realities, in this case, how teacher learning for diversity was shaped in the local TEIP interventions. Following the vision of Atkinson and Coffey (2011) that documents are not '[...] transparent representations of 
organisational routines, decision-making processes or professional practice' ( $\mathrm{p}$. 79), it was assumed that documents create a particular 'documentary reality'. Three types of documents were identified as insightful in answering the research questions: the schools' TEIP Improvement Plan, Educational Plan, and Professional Development Plan. These documents were obtained through a manual online search on the websites of the 137 TEIP school clusters. School clusters that did not display TEIP Improvement Plans were excluded from the search ( 42 school clusters). A typology was developed for delineating the documentation types of the school clusters 1) schools with only TEIP Improvement Plan (17 school clusters); 2) schools with Improvement Plan and Educational Plan (59 school clusters); 3) schools with Improvement Plan and Professional Development Plan (4 school clusters); 4) schools having all three documents (15 school clusters). A total of 188 documents from 95 TEIP schools were analysed.

The analysis was guided by the principles of contextual policy analysis (Ritchie \& Spencer, 1994) that identifies the forms and nature of a certain existing phenomenon in policies. The analysis followed the procedures of inductive content analysis (Mayring, 2014) using NVivo version 11 software. Mayring's (2014, p. 80) steps of inductive category development includes 1) focusing on theories and research questions; 2) defining selection criteria; 3 ) initial category formulation; 4) revision and definition of categories half-way through the material; 5) coding the rest of the material; 6) building main categories; 7) intra/ inter-code agreement; 8) final results, interpretation. Following these steps, an initial selection protocol was developed, guided by theoretical perspectives and research questions. The material was divided between the two researchers and was analysed independently. After an analysis of around $50 \%$ of the whole data, the initial codes and categories were reviewed, discussed, and agreed upon between the researchers, and the rest of the data was analysed independently. The researchers then reviewed their individual analysis for refinements and main category building. The final step involved an audit of each other's analysis and inter-coding agreement. The first level analysis investigated the forms of teacher learning and identified four main themes that were used as the structure of the Findings section. The second level analysis explored the contents of each form of teacher learning, specifically focusing on if and how diversity was situated within those forms of teacher learning.

\section{Results}

The first level analysis revealed four main potential forms of teacher learning 1) learning together; 2) pedagogical supervision; 3) reflection; 4) 
professional development courses. These themes will be described, coupled with the second level analysis of how diversity was situated within each theme.

\section{Learning together}

A strong theme emerging was 'teachers working together' to reach the TEIP goals. However, this initiative took a variety of forms and was signalled by mixed terminology, often using 'working together', 'cooperation', and 'collaboration' interchangeably or simply as a list of descriptive words without theoretical distinction. Therefore, we will refer to this category as 'learning together', while acknowledging its many levels and modes existing in the documents. Despite the variability, there are some trends based on the programmes 'Mais Sucesso Escolar/ TurmaMais' and 'Fenix', which mainly target literacy- and numeracy-related 'school failure'. For example, a set of interventions recruited an extra support teacher. The work of the two teachers included: splitting classes into two groups and teaching students separately with or without prior teacher cooperation; the support teacher helping students within the classroom, individually or in small groups, following the main teacher's curriculum; and coteaching with two teachers planning and conducting lessons collaboratively. The TEIP documents are consistent in arguing that such actions were necessary to provide differentiated, individualised teaching and learning as a means of responding to students' needs.

Other forms of 'learning together' consisted of establishing working groups between teachers, departments and disciplines; teamwork (including interdisciplinary teams), working in partnerships/networks with external experts, and the idea of a learning community was also mentioned. These forms usually aimed at teachers developing together assessment instruments, lesson plans, teaching strategies and materials, and projects. Another aim of these forms was to share good practices, experiences, instruments and resources among the teaching team. Almost no reference was made on how these forms of collaboration address diversity, and only a few documents mentioned that teachers should work together with a Special Education teacher.

The actors of 'learning together' were teachers' horizontal (subject) and vertical pairs and groups, teachers with support staff, leadership and external experts. Even though TEIP aims to strengthen school-community relations, which could easily imply teachers learning with/from students and families, community-related actions were mostly associated with support staff (social workers, psychologists, and animators) rather than teachers. 


\section{Pedagogical supervision}

Even though pedagogical supervision could be clustered under the 'learning together' theme, as it implies teachers observing each other's lessons and reflecting on them, it emerged in the data as a standalone activity that leads to modifying practices. 'Pedagogical supervision', also referred to as 'intervision' in some schools, meant either middle leadership or peers to observe lessons. Pedagogical supervision was regarded as an effective form of professional development that contributed to the improvement of teaching practice, and eventually, student learning. Lesson study, critical friends, and coaching were also mentioned a few times, meaning a similar type of action. The aims and contents of these dynamics were kept on the level of 'improving practices' or 'modifying strategies' without specifically targeting diversity.

\section{Reflection}

Reflection was often mentioned in school policy documents, with schools stating that reflecting was a significant cornerstone to the refinement and adaptation of teaching strategies and TEIP actions, ultimately raising school results. Thus, reflection meant both 'reflecting on practices' and 'reflecting on results' mostly related to TEIP targets: academic results, the frequency of indiscipline, absenteeism, and dropout. In other words, reflection was often associated with the schools' self-assessment and monitoring of the development and impact of TEIP actions, which was performed by teams of teachers but was not centred on teachers' self-development. Critical reflection was mentioned only a few times, and there was a lack of specifying reflection on practices in terms of responding to diversity, or in relation to mechanisms of exclusion and inclusion in society and in school. Apart from what was mentioned regarding 'pedagogical supervision', there was no clear sign of encouraging teachers to reflect on themselves, their own assumptions, beliefs, and attitudes towards students, families, and communities.

\section{In-service courses}

The majority of the TEIP school policies analysed provided a list of courses available for teachers. These courses or workshops differed in contents, lengths, and ways of being organised. The courses were mostly provided through the centres for continuing professional development connected to the schools. The teachers were allowed to visit other schools and institutions for 
professional development, and the TEIP 'external expert' also seemed to provide in-school workshops. Regarding content, courses were mostly provided around three main areas: subject-specific contents, transversal knowledge and classroom management, and knowledge and skills related to the specific TEIP actions.

Regarding subject-specific courses, contents were mainly related to Portuguese, Mathematics, and experimental teaching of Sciences. Transversal knowledge and skills involved a variety of contents, such as differentiated curriculum and pedagogy, using ICT, active teaching, assessment methods, and classroom management. Classroom management was generally related to student behaviour and to the TEIP target of 'Preventing Indiscipline'. Courses related to TEIP actions, such as specific teaching strategies (TurmaMais, Fénix, tutoring), monitoring and self-assessment, and pedagogical supervision, were also offered.

Contents related to diversity appeared in the transversal category, mostly around special education and inclusion. To a smaller extent, 'inter/multiculturality', 'integration', and 'PNML' were also present. The titles and terminologies of these courses differed across the schools and tended to use overlapping concepts of inclusion, integration, and inter/multiculturality. For example, 'inclusion' was mostly used in referring to 'SEN', or to diversity in general. 'Integration' was often mentioned broadly or in terms of 'Roma ethnicity', 'SEN' or 'PNML' students. 'Inter/multiculturality' was usually a broad topic without specificities. However, in a few cases, the course titles presented problematic perspectives of diversity, for example, 'Integrating students of Roma ethnicity to school: a problem or an opportunity? Managing cultural diversity in school.

\section{Discussion and Conclusions}

This article aimed to explore if and how TEIP promoted teacher learning in general, and specifically learning for diversity, through its initiatives for in-service teachers' professional development.

Starting with whether TEIP promoted teacher learning, it was clear that school policies mentioned several opportunities for teacher learning, such as working and learning together, pedagogical supervision, reflection and professional development courses. Improving teaching was regarded as a crucial component of TEIP, and it was consistently assumed to lead to improving student learning, and ultimately, school results. Aligned with previous literature (Vangrieken et al., 2015, Vescio et al., 2008), the schools have shown awareness of the need for building collaborative working cultures, and encouraging teacher 
learning through a variety of initiatives to work and learn together. However, the monitoring of the impact of TEIP actions was often reduced to measuring three TEIP targets: student grades, levels of indiscipline, and school dropout. Despite the clear commitment in TEIP school policies to support teachers' professional development in collaborative environments, it is ambiguous whether these initiatives can have a strong impact on actual teaching practices when constrained by such narrowly defined indicators of assessment.

Learning together activities mostly involved teachers, school leadership, support staff, and external experts, but students, families, and communities seemed to be completely missing from these initiatives. As previously pointed out (Abrantes et al., 2013; Ferraz et al., 2014), TEIP actions for strengthening school, family, and community relationships remain underdeveloped. Our analysis found a variety of activities targeting the involvement of parents and communities in school life, but they did not seem to be opportunities for teacher learning, rather the other way around, the actions promoted 'parents learning' by learning from support staff and school. Therefore, it seemed to be assumed in TEIP-related documents that students, families and communities are not legitimate sources of teacher learning, in other words, are not regarded as equal partners in the teaching-learning process. Despite the fact that engaging with communities and student voice (Coffey, 2010; Lees, 2016; Messiou et al., 2016; Schultz, 2003; Simon et al., 2018) is crucial in transformation for diversity and equity, TEIP actions seemed to reinforce an image of school and teachers that might hinder the development of inclusive schools.

Diversity appeared in the TEIP documents when describing the schools' contexts, students, and families, mostly pointing to the dimensions of SEN, ethnicity, nationality, language, socio-economic status, and educational success as measured by grades and grade repetition. In most cases, diversity was simultaneously presented as an opportunity in the school values sections, and as a challenge or problem, in the schools' contextualisation and specific TEIP actions. However, the lack of diversity focus was evident in the initiatives for teachers' professional development.

There was a clear awareness of the need to differentiate teaching, and for teachers to learn about differentiation; however, the rationale for this was not diversity but the improvement of students' grades, especially in Portuguese and Maths. Reflection, another strong component of teacher learning in TEIP, was consistently identified in the documents as a crucial process for improving practice. Teachers were encouraged to reflect mainly on the students' results and on teaching practice in general, and to modify practices, leading to improved school results. Similarly to teachers' 'learning together' activities, the 
aims and contents of these reflections either remained on a global level, without an emphasis on diversity or focused on reflection about grades, indiscipline and school dropout. Consistently with what was presented by Canário (2004), the teacher reflections may lead to explanations of 'problems' as being within students and their families, which can create further obstacles in developing a critical reflection on how TEIP practices contribute to or hinder tackling social inequalities. Without an understanding of diversity and social justice practices, these initiatives might eventually lead to the opposite effect, such as labelling and tracking students in fixed ability groups, contributing to certain groups of students to remaining in low-achieving paths of academic and professional life. Critical reflection on the self, one's beliefs, and assumptions seemed to be completely absent from the reflection processes. Thus, if teachers hold low expectations and negative views about their students (Ainscow, 2005), transformation is unlikely to happen. Therefore, the teachers' ability to act and think critically is crucial in counteracting such ambiguities (Dyson et al., 2003), for example by understanding and modifying group compositions and arrangements from an inclusive point of view, keeping high expectations for all learners and examining ones' biases.

Regarding professional development courses, largely promoted topics of teacher learning indirectly connected to diversity were 'differentiated pedagogy' and 'curricular differentiation', but these seemed to remain on a superficial or technical level, which does not necessarily engage with how diversity is targeted through these actions. In contrast, the more specific courses, focused on 'special education', 'inclusion, 'integration', 'inter/multiculturality', and 'PNML', will depend greatly on how these issues will be approached and by whom, risking complying with superficial approaches that do not engage teachers' in critical thinking and questioning the status quo of schooling. Additionally, some of the courses seemed to apply confusing principles related to ethnicity, language status, integration, and inclusion. Furthermore, a variety of crucial topics were seemingly missing from these courses, including (among others) equity and social justice, multilingual pedagogies, cultural responsiveness, discrimination, and racism. Some dimensions of diversity remained overlooked, such as gender, sexuality, and religion. Approaches that view student diversity through inclusive, intersectional lenses also seemed to be absent. However, the documents only provided the titles of the courses, and this analysis cannot offer a conclusion about their actual contents.

Ultimately, the success of the TEIP actions being assessed through its impact on students' academic achievement or indiscipline creates a strong barrier to developing inclusive and equitable schools and transforming education 
in TEIP (Abrantes et al., 2011, 2013; Dyson et al., 2003). Our analyses found that these standards of measurements, in fact, disregard both diversity and teachers' professional learning for diversity. Consequently, despite the fact that professional development is essential to improve student learning (Hattie, 2003; Vermunt, 2014), teacher learning within TEIP documents seems to remain instrumental to raising school success, rather than being at the core of transforming education and schools into an asset for a more equitable and socially just society.

These results call for TEIP policies to support teacher learning for diversity, in other words, continuing professional development that fosters critical thinking and engages with communities' and students' voices in order to respond to diversity aiming to create equitable practices and tackling exclusion. These findings might serve as starting points to renew TEIP, as well as other ABIs in Europe.

\section{Acknowledgement}

The paper is part of the European Doctorate in Teacher Education (EDiTE) project that has received funding from the European Union's Horizon 2020 research and innovation programme under Marie Sklodowska-Curie grant agreement number 676452 .

\section{References}

Abrantes, P., Roldão C., \& Mauritti R. (2011). Efeitos TEIP: Avaliação de impactos escolares e sociais em sete territórios educativos de intervenção prioritária. Síntese dos resultados [Effects of TEIP: An evaluation of the academic and social impacts in seven territories of educational priority intervention. A syntheis of results]. Lisbon: Direção-Geral de Inovação e Desenvolvimento Curricular (DGIDC) Ministério da Educação

Abrantes, P., Roldão, C., Amaral P., \& Mauritti, R. (2013). Born to fail? Some lessons from a national programme to improve education in poor districts. International Studies in Sociology of Education, 23(1), $17-38$.

Ainscow, M. (2005). Developing inclusive education systems: What are the levers for change? Journal of Educational Change, 6(2), 109-124.

Ainscow, M. (2016). Diversity and equity: A global education challenge. New Zealand Journal of Educational Studies, 51(2), 143-155.

Arnesen, A-L., Birzea, C., Dumont, B., Essomba, M. A., Furch, E., Vallianatos, A., \& Ferrer, F. (2008). Policies and practices for teaching socio-cultural diversity. Strasbourg: Council of Europe Publishing. Atkinson, P., \& Coffey, A. (2011). Analysing documentary realities. In D. Silverman (Ed.), Qualitative 
research: Issues of theory, method and practice (pp. 77-93). London, UK: Sage.

Avalos, B. (2011). Teacher professional development in teaching and teacher education over ten years.

Teaching and Teacher Education, 27(1), 10-20.

Bakkenes, I., Vermunt, J. D., \& Wubbels, T. (2010). Teacher learning in the context of educational innovation: Learning activities and learning outcomes of experienced teachers. Learning and Instruction, $20(6), 533-548$.

Borko, H. (2004). Professional development and teacher learning: Mapping the terrain. Educational Researcher, 33(8), 3-15.

Burbank, M. D., \& Kauchak, D. (2003). An alternative model for professional development: Investigations into effective collaboration. Teaching and Teacher Education, 19(5), 499-514.

Burns, T., \& Shadoian-Gersing, V. (2010). The importance of effective teacher education for diversity. In T. Burns, V. Shadoian-Gersing, J. Bouch, T. Walsh, \& C. Davis (Eds.), Educating teachers for diversity: Meeting the challenge (pp. 19-40). Paris: OECD Publications.

Caena, F. (2011). Literature review. Quality in teachers' continuing professional development. Retrieved from http://ec.europa.eu/dgs/education_culture/repository/education/policy/strategic-framework/doc/ teacher-development_en.pdf

Canário, R. (2004). Territórios educativos e políticas de intervenção prioritária: Uma análise crítica [Educational territories and priority intervention policies: A critical analysis]. Perspectiva, Florianópolis, $22(1), 47-78$.

Cardona Moltó, M., Florian, L., Rouse, M., \& Stough, L. M. (2010). Attitudes to diversity: A crosscultural study of education students in Spain, England and the United States. European Journal of Teacher Education, 33(3), 245-264.

Carlos, A. P., Cardoso, S., Galante, S., Lamy, F., Silva, P., Gaspar, I., \& Seabra, F. (2017). Supervision in continuous teacher training. Enseñanza and Teaching: Revista Interuniversitaria de Didáctica, 35(1), $185-206$.

Coffey, H. (2010). 'They taught me': The benefits of early community-based field experiences in teacher education. Teaching and Teacher Education, 26(2), 335-342.

Cordingley, P., \& Buckler, N. (2014). Pulling learning through: Building the profession's skills in making use of workplace coaching opportunities. In O. McNamara, J. Jean, \& M. Jones (Eds.), Workplace learning in teacher education: International practice and policy (pp. 121-135). New York, NY: Springer.

Council of Europe (2009). Diversity and inclusion: Challenges for teacher education. Key competences for diversity. Strasbourg: Directorate general IV - Directorate of Education and Languages Unit of European Education Policies.

Council of Europe (2016). Competences for democratic culture: Living together as equals in culturally diverse democratic societies. Strasbourg: Council of Europe Publishing.

Creemers, B., Kyriakides, L., \& Antoniou, P. (2013). Teacher professional development for improving quality of teaching. Dordrecht: Springer.

Darling-Hammond, L. (2017). Teacher education around the world: What can we learn from international practice? European Journal of Teacher Education, 40(3), 291-309. 
Day, C., \& Sachs, J. (2004). International handbook on the continuing professional development of teachers. Maidenhead, UK: Open University Press.

Dyson, A., Gallannaugh, F., \& Millward, A. (2003). Making space in the standards agenda: developing inclusive practices in schools. European Educational Research Journal, 2(2), 228-244.

Dyson, A., Raffo, C., \& Rochex, J. Y. (2014). Les PEP à ciblage territorial [The PEPs targetting territories].

In M. Demeuse, D. Frandji, D. Greger, \& J. Y. Rochex (Eds.), Les politiques déducation prioritaire en Europe (pp. 105-134). Lyon: Open Edition Books.

Essomba, M. A. (2010). Teacher education for diversity in Spain: Moving from theory to practice In T. Burns, V. Shadoian-Gersing, J. Bouch, T. Walsh, \& C. Davis (Eds.), Educating teachers for diversity: Meeting the challenge (pp. 219-235). Paris: OECD Publications.

European Commission. (2013). Supporting teacher competence development for better learning outcomes.

Retrieved from http://ec.europa.eu/dgs/education_culture/repository/education/policy/school/doc/ teachercomp_en.pdf

European Commission. (2015). Language teaching and learning in multilingual classrooms. Luxembourg: Publications Office of the European Union.

European Commission. (2017). Preparing teachers for diversity: The role of initial teacher education. Luxembourg: Publications Office of the European Union.

European Agency for Development in Special Needs Education. (2012). Teacher education for inclusion: Profile of inclusive teachers. Brussels: European Agency.

Ferraz, H., Enes, D., Neves, T., \& Nata, G. (2014). O impacto do programa TEIP nos resultados dos exames nacionais ao longo de 12 anos [The impact of the TEIP programme in the results of national exams along 12 years]. In Entre crise e euforia: Práticas e políticas educativas no Brasil e em Portugal (pp. 1281-1308). Porto: Universidade do Porto.

Flores, M. A. (2005). How do teachers learn in the workplace? Findings from an empirical study carried out in Portugal. Journal of In-service Education, 31(3), 485-508.

Flores, M. A., \& Ferreira, F. I. (2016). Education and child poverty in times of austerity in Portugal: Implications for teachers and teacher Education. Journal of Education for Teaching: International Research and Pedagogy, 42(4), 404-416.

Florian, L. (2012). Preparing teachers to work in inclusive classrooms: Key lessons for the professional development of teacher educators from Scotland's inclusive practice project. Journal of Teacher Education, $63(4), 275-285$.

Gay, G. (2013). Teaching to and through cultural diversity. Curriculum Inquiry, 43(1), 48-70.

Gilbert, R. (2011). Professional Learning flagship Program: Leading curriculum change. Literature Review. Melbourne: Australian Institute for Teaching and School Leadership.

Guerriero, S. (Ed.). (2017). Pedagogical knowledge and the changing nature of the teaching profession. Paris: OECD Publishing.

Guskey, T. (2000). Evaluating professional development. Thousand Oaks, CA: Corwin Press.

Hattie, J. (2003). Teachers make a difference: What is the research evidence? Paper presented at the Building Teacher Quality: What does the research tell us ACER Research Conference. Melbourne: ACER. 
Hattie, J. (2009). Visible Learning: A synthesis of over 800 meta-analyses relating to achievement. London, UK: Routledge.

Hattie, J. (2015). The applicability of visible learning to higher education. Scholarship of Teaching and Learning in Psychology, 1(1), 79-91.

Hoban, G. F. (2002). Teacher learning for educational change: A systems thinking approach. Buckingham UK: Open University Press.

Kemmis, S., Heikkinen, H. L., Fransson, G., Aspfors, J., \& Edwards-Groves, C. (2014). Mentoring of new teachers as a contested practice: Supervision, support and collaborative self-development. Teaching and Teacher Education, 43, 154-164.

Kerr, K., \& Dyson, A. (2017). Area-based responses to educational disadvantage. In G.W. Noblit (Ed.), Oxford Research Encyclopedia of Education (pp. 1-23). Retrieved from http://education.oxfordre.com/ view/10.1093/acrefore/9780190264093.001.0001/acrefore-9780190264093-e-16o

Lees, A. (2016). Roles of urban indigenous community members in collaborative field-based teacher preparation. Journal of Teacher Education, 67(5), 363-378.

Lupton, R. (2010). Area-based initiatives in English education: What place for place and space? In C. Raffo, A. Dyson, H. Gunter, D. Hall, L. Jones, \& A. Kalambouka (Eds.), Education and poverty in affluent countries (pp. 111-134). London, UK: Routledge.

Mayring, P. (2014). Qualitative content analysis: theoretical foundation, basic procedures and software solution. Retrieved from http://nbn-resolving.de/urn:nbn:de:0168-ssoar-395173

Meirink, J. A., Meijer, P. C., Verloop, N., \& Bergen, T. C. (2009). How do teachers learn in the workplace? An examination of teacher learning activities. European Journal of Teacher Education, 32(3), 209-224.

Menter, I., Hulme, M., Elliot, D., \& Lewin, J. (2010). Literature review on teacher education in the 21st century. Edinburgh, UK: Scottish Government Social Research.

Messiou, K., Ainscow, M., Echeita, G., Goldrick, S., Hope, M., Paes, I., \& Vitorino, T. (2016). Learning from differences: A strategy for teacher development in respect to student diversity. School Effectiveness and School Improvement, $27(1), 45-61$.

Murata, A. (2011). Introduction: Conceptual overview of lesson study. In L. C. Hart, A. Alston, \& A. Murata (Eds.), Lesson study research and practice in mathematics education (pp. 1-12). Dordrecht: Springer.

OECD. (2010). Educating teachers for diversity: Meeting the Challenges. Paris: OECD Publications.

Read, K., Aldridge, J., Ala’i, K., Fraser, B, \& Fozdar, F. (2015). Creating a climate in which students can flourish: A whole school intercultural approach. International Journal of Whole Schooling, 11(2), 29-44. Révai, N., \& Guerriero, S. (2017). Knowledge dynamics in the teaching profession. In S. Guerriero (Ed.), Pedagogical knowledge and the changing nature of the teaching profession (pp. 37-71). Paris: OECD Publishing.

Ritchie, J., \& Spencer, L. (1994). Qualitative data analysis for applied policy research. In A. Bryman \& R. G. Burgess (Eds.), Analysing qualitative data (pp. 173-194). London, UK: Routledge.

Rolo, C., Prata, M., \& Dias, M. (2014). Learning and teaching in at-risk Contexts: What Strategies? What Results? Procedia - Social and Behavioral Sciences, 116, 1837-1841. Retrieved from https://ac.els- 
cdn.com/S1877042814004972/1-s2.o-S1877042814004972-main.pdf?_tid=6b31db53-fd7o-4c1a-bb6df6629b2186c4\&acdnat $=1537169595$ fo3d22d288ff34c218dab8055657b8a8

Schultz, K. (2003). Listening: A framework for teaching across differences. New York, NY: Teachers College Press.

Sampaio, M., \& Leite, C. (2015). Curricular justice: Influences of TEIP program and school. External evaluation process. In C. Leite, P. Fernandes, \& A. Mouraz (Eds.), Curriculum studies: Policies, perspectives and practices (pp. 72-80). Porto: CIIE

Simón, C., Echeita, G., \& Sandoval, M. (2018). La incorporación de la voz del alumnado a la 'Lesson Study' como estrategia de formación docente y mejora para la inclusión [Incorporating students' voices in the 'Lesson Study' as a teacher-training and improvement strategy for inclusion]/inclusion. Cultura $y$ Educación, 3o(1), 1-21.

Putnam, R. T., \& Borko, H. (2000). What do new views of knowledge and thinking have to say about research on teacher learning? Educational researcher, 29(1), 4-15.

Silva, M., da Silva, S. M., \& Araújo, H. C. (2017). Networking in education: From concept to action An analytical view on the Educational Territories of Priority Intervention (TEIP) in Northern Portugal. Improving Schools, 2o(1), 48-61.

Teemant, A., Cen, Y., \& Wilson, A. (2015). Effects of ESL instructional coaching on secondary teacher use of sociocultural instructional practices. INTESOL Journal, 12(2), 1-29.

Timperley, H., \& Alton-Lee, A. (2008). Reframing teacher professional learning: An alternative policy approach to strengthening valued outcomes for diverse learners. Review of Research in Education, 32(1), 328-369.

Timperley, H. (2008). Teacher professional learning and development. Brussels: International Bureau of Education.

UNESCO (2005). Guidelines for inclusion: Ensuring access to education for all. Paris: UNESCO.

Vangrieken, K., Dochy, F., Raes, E., \&. Kyndt, E (2015). Teacher collaboration: A systematic review. Educational Research Review, 15, 17-40. Retrieved from http://daneshyari.com/article/preview/355080. pdf

Vermunt, J. D. (2014). Teacher learning and professional development. In S. Krolak-Schwerdt, S. Glock, \& M. Böhmer (Eds.), Teachers' professional development: Assessment, training and learning (pp. 79-97). Rotterdam: Sense Publishers.

Vermunt, J. D., \& Endedijk, M. D. (2011). Patterns in teacher learning in different phases of the professional career. Learning and Individual Differences, 21(3), 294-302.

Vescio, V., Ross, D., \& Adams, A. (2008). A review of research on the impact of professional learning communities on teaching practice and student learning. Teaching and Teacher Education, 24(1), 80-91.

Waitoller, F. R., \& Artiles, A. J. (2013). A decade of professional development research for inclusive education: A critical review and notes for a research program. Review of Educational Research, 83(3), 319-356.

Webster-Wright, A. (2009). Reframing professional development through understanding authentic professional learning. Review of Educational Research, 79(2), 702-739. 


\section{Biographical note}

Nikolett Szelei is an early stage researcher in teacher education at the Institute of Education, University of Lisbon. Her main areas of research include cultural and linguistic diversity in schools, focusing on critical multiculturalism, social justice and students' voices; and teachers' context-based experiences and professional development on the same fields. Other areas of interest include preschool and primary school education, teacher collaboration, mentoring, and music education.

Ines Alves, PhD, is a Lecturer in Inclusive Education at the University of Glasgow. Her research interests are inclusive education, social justice and equity, human rights, and disability. She is interested in the conceptualisation of difference, and in the schools' responses to pupil diversity, namely through the use of inclusive pedagogy and Universal Design for Learning. 